\title{
BET Inhibitor ABBV-744
}

National Cancer Institute

\section{Source}

National Cancer Institute. BET Inhibitor ABBV-744. NCI Thesaurus. Code C148415.

An orally bioavailable inhibitor of the Bromodomain and Extra-Terminal (BET) family of proteins, with potential antineoplastic activity. Upon oral administration, the BET inhibitor ABBV-744 preferentially binds to the second bromodomain (BD2) of BET proteins, thereby preventing the interaction between the BET proteins and acetylated histones. This disrupts chromatin remodeling and gene expression. Prevention of the expression of certain growth-promoting genes may lead to an inhibition of proliferation in BEToverexpressing tumor cells. BET proteins, comprised of BRD2, BRD3, BRD4 and BRDT, are transcriptional regulators that contain two homologous bromodomains, the BD1 and BD2 domains. They play an important role during development and cellular growth. 